\title{
Influence of selenium on growth, lipid peroxidation and antioxidative enzyme activity in melon (Cucumis melo L.) seedlings under salt stress
}

\author{
Hu KeLing ${ }^{1 *}$, Zhang Ling ${ }^{1}$, Wang JiTao ${ }^{2}$, You Yang ${ }^{1}$ \\ 'Department of Horticulture, Anhui Agriculture University, 130 West Chang jiang Road, HeFei, Anhui 230036, China \\ ${ }_{2}^{2}$ China Tobacco Anhui Industrial Co., LTD HeFei, Anhui 230088, China
}

\section{Abstract}

The objective of this study was to investigate the effect of exogenous selenium (Se) supply $(0,2,4,8,16 \mu \mathrm{M})$ on the growth, lipid peroxidation and antioxidative enzyme activity of $100 \mathrm{mM} \mathrm{NaCl}$-stressed melon (Cucumis melo L.) seedlings. Salt stress significantly reduced the growth attributes including stem length, stem diameter, dry weight and increased antioxidative enzyme activity [superoxide dismutase (SOD), peroxidase (POD), catalase (CAT)]. Moreover, the plant exhibited a significant increase in electrolyte leakage and malondialdehyde (MDA) content under $\mathrm{NaCl}$ stress. Se supplementation not only improved the growth parameters but also successfully ameliorated the adverse effect caused by salt stress in melon seedlings. However, the mitigation of $\mathrm{NaCl}$-stressed seedlings was different depending on the Se concentration. At lower concentrations $(2-8 \mu \mathrm{M})$, Se improved growth and acted as antioxidant by inhibiting lipid peroxidation and increasing in SOD and POD enzymes activity under salt stress. At higher concentrations $(16 \mu \mathrm{M})$, Se exerted diminished beneficial effects on growth. Whereas CAT activity was enhanced. The result indicated that Se supplementation had a positive physiological effect on the growth and development of salt-stressed melon seedlings.

Keywords: Cucumis melo L., selenium, salt stress

\section{Introduction}

Salt stress is a major abiotic stress reducing the productivity of crops in many areas of the world, despite the advanced management techniques developed in recent years [1]. Saltinduced ion toxicity, nutritional disruption and water deficit lead to the overproduction of reactive oxygen species (ROS) [2], such as superoxide $\left(\mathrm{O}_{2}^{-}\right)$hydrogen peroxide $\left(\mathrm{H}_{2} \mathrm{O}_{2}\right)$, and hydroxyl radical $(\cdot \mathrm{OH})[3]$. Plants possess an antioxidant system to mitigate the negative effects of ROS [4]. This system evolves enzymatic and non-enzymatic antioxidants, of which antioxidant enzymes include superoxide dismutase (SOD), catalase (CAT), peroxidase (POD) and other enzymes of the ascorbate-glutathione cycle [5].

However, notwithstanding considerable effort over decades, there is no significant progress on preventing negative effects of salt stress. Selenium (Se) is an essential micronutrient and has important benefits for humans and animals nutrition [6]

* Corresponding author. Email: klhu@ahau.edu.cn

Handling Editor: Grażyna Kłobus

This is an Open Access digital version of the article distributed under the terms of the Creative Commons Attribution 3.0 License (creativecommons.org/licenses/by/3.0/), which permits redistribution, commercial and non-commercial, provided that the article is properly cited. and has been recognized to ameliorate the adverse effects of stress by improving antioxidant activity that can stimulate plant growth [7]. Many reports have shown that Se can have a hopeful influence on plant and may play a role in plant protection from several types of abiotic stresses, such as salt $[8,9]$, chilling [10], and heavy metals [11]. However, it is not known if exogenous Se treatment also induces salt stress tolerance in melon (Cucumis melo L.) seedlings. Thus, the aim of the present study was to investigate the effectiveness of Se application in the alleviation of salt stress by ameliorating plant growth, the level of lipid peroxidation and enzymes activities.

\section{Material and methods}

\section{Plant materials, growth conditions and treatments}

Seeds of melon (Cucumis melo L.) were purchased from Hefei agriculture market. Seeds were sown on growth medium containing a mixture of peat and vermiculite $(7: 3, \mathrm{v}: \mathrm{v})$ in greenhouse. When the first true leaf was fully expanded, seedlings were grown in Hoagland's nutrient solution $\left[\mathrm{Ca}\left(\mathrm{NO}_{3}\right)_{2} \cdot 4 \mathrm{H}_{2} \mathrm{O}\right.$ $4 \mathrm{mM}, \mathrm{KNO}_{3} 6 \mathrm{mM}, \mathrm{NH}_{4} \mathrm{H}_{2} \mathrm{PO}_{4} 1 \mathrm{mM}, \mathrm{MgSO}_{4} \cdot 7 \mathrm{H}_{2} \mathrm{O}$ $2 \mathrm{mM}, \mathrm{Na}_{2} \mathrm{Fe}$-EDTA $81 \mu \mathrm{M}, \mathrm{FeSO}_{4} 99 \mu \mathrm{M}, \mathrm{H}_{3} \mathrm{BO}_{3} 46 \mu \mathrm{M}$, $\mathrm{MnCl}_{2} \cdot 4 \mathrm{H}_{2} \mathrm{O} 9 \mu \mathrm{M}, \mathrm{ZnSO}_{4} \cdot 7 \mathrm{H}_{2} \mathrm{O} 0.77 \mu \mathrm{M}, \mathrm{CuSO}_{4} \cdot 5 \mathrm{H}_{2} \mathrm{O} 0.32$ $\left.\mu \mathrm{M},\left(\mathrm{NH}_{4}\right)_{6} \mathrm{Mo}_{7} \mathrm{O}_{24} \cdot 4 \mathrm{H}_{2} \mathrm{O} 0.02 \mu \mathrm{M}\right]$. There were 8 seedlings per $10 \mathrm{l}$ pot. The nutrient solutions were aerated continuously with an air bubbler. The growth conditions were as follows: photoperiod of $14 / 10 \mathrm{~h}$ (day/night), temperature of $25 / 17^{\circ} \mathrm{C}$ 
(day/night), and the maximal photosynthetic photon flux density of $600 \mu \mathrm{mol} \mathrm{m}{ }^{-2} \mathrm{~s}^{-1}$.

When the third true leaves were fully expanded, seedlings were employed to treatments. Detailed treatments were as follows: Control (T0), $100 \mathrm{mM} \mathrm{NaCl}+0 \mu \mathrm{M}$ Se (applied as $\mathrm{Na}_{2} \mathrm{SeO}_{3}$; T1), $100 \mathrm{mM} \mathrm{NaCl}+2 \mu \mathrm{M} \mathrm{Se}(\mathrm{T} 2), 100 \mathrm{mM} \mathrm{NaCl}+$ $4 \mu \mathrm{M}$ Se (T3), $100 \mathrm{mM} \mathrm{NaCl}+8 \mu \mathrm{M}$ Se (T4), $100 \mathrm{mM} \mathrm{NaCl}+$ $16 \mu \mathrm{M}$ Se (T5). Each treatment had three replicates. All of following measurements were carried out using samples collected around 10 days after processing.

\section{Growth analysis}

Stem length was surveyed by ruler. Stem diameter was measured with vernier caliper. And plant dry mass was determined after drying the plant at $80^{\circ} \mathrm{C}$ to a constant weight.

\section{Lipid peroxidation}

Lipid peroxidation was estimated by measuring the content of malondialdehyde (MDA) using the thiobarbituric acid (TBA) assays as described by Yao et al. [12]. Leaves tissues ( $0.5 \mathrm{~g})$ were extracted in a solution of $20 \%(\mathrm{w} / \mathrm{v})$ trichloroacetic acid containing $0.5 \%(\mathrm{w} / \mathrm{v})$ TBA and $4 \%(\mathrm{w} / \mathrm{v})$ butylated hydroxytoluene. The mixture was heated at $95^{\circ} \mathrm{C}$ for $30 \mathrm{~min}$, MDA content was estimated by measuring A532-A600 and using a molar absorption coefficient of $155 \mathrm{mM}^{-1} \mathrm{~cm}^{-1}$.

\section{Electrolyte leakage}

Membrane permeability was evaluated by the relative electrolyte leakage according to the method of Syeed et al. [13]. Leaf samples were thoroughly washed with double distilled water for $25^{\circ} \mathrm{C}$ at $6 \mathrm{~h}$ using rotatory shaker. Subsequently, electrical conductivity $(E C)$ was determined $(E C 1)$. Samples were then again kept at $90^{\circ} \mathrm{C}$ for $2 \mathrm{~h}$ and then $E C 2$ was recorded after attaining equilibrium at $25^{\circ} \mathrm{C}$.

Electrolyte leakage $(\%)=(E C 1 / E C 2) \times 100$

\section{Analyses of antioxidant enzyme activity}

For the enzyme assays, leaves $(0.3 \mathrm{~g})$ were grounded with a $2 \mathrm{ml}$ ice-cold buffer containing $50 \mathrm{mM}$ phosphate buffer solution ( $\mathrm{pH} 7.8$ ), $0.2 \mathrm{mM}$ ethylenediamine-tetraacetic acid, $2 \mathrm{mM}$ Ascorbate and $2 \%(\mathrm{w} / \mathrm{v})$ polyvinyl polypyrrolidone. The homogenates were centrifuged at $12100 \mathrm{~g}$ for $15 \mathrm{~min}$ at $4^{\circ} \mathrm{C}$ and the resulting supernatants were collected for the determination of enzyme activity. All operations were performed at $4^{\circ} \mathrm{C}$. SOD activity was assayed by the photochemical method as described by Stewart \& Bewley [14]. The activity of POD and CAT was measured using the method of Cakmak \& Marschner [15]. In this study, we used USA Beckman Kurt DU 800 spectrophotometer for the relevant indicators.

\section{Statistical analysis}

Measurements were analyzed using SAS 8.0 (SAS Institute, Cary, NC) for the general linear models (GLM) procedure. The least significant difference (LSD) was used to compare the means.

\section{Results}

\section{Plant growth}

As shown in Tab. 1, significant reduction was observed in melon seedling growth (stem length, stem diameter, dry weight) under salt stress compared to the control. Authors found Se supplementation with different concentrations promoted melon seedling growth better than $\mathrm{NaCl}$-stressed plants grown without Se addition. However, all of Se treatments of melon seedlings growth were lower than control. Our results revealed that at low concentrations $(2-8 \mu \mathrm{M})$, Se relieved the growth of NaClstressed seedlings, especially $8 \mu \mathrm{M}$ of Se treatment. A negative effect of Se on growth was apparent at high concentration of $16 \mu \mathrm{M}$ Se.

Tab. 1 Effects of Se supplementation on growth of $\mathrm{NaCl}$-stressed melon seedlings.

\begin{tabular}{lccc} 
Treatments & Stem length $(\mathbf{c m})$ & Sem diameter $(\mathbf{m m})$ & Dry weight $(\mathbf{g})$ \\
\hline T0 & $8.55 \pm 0.32 \mathrm{a}$ & $3.23 \pm 0.17 \mathrm{a}$ & $0.46 \pm 0.03 \mathrm{a}$ \\
T1 & $7.33 \pm 0.49 \mathrm{c}$ & $2.84 \pm 0.07 \mathrm{~d}$ & $0.23 \pm 0.03 \mathrm{~d}$ \\
T2 & $7.92 \pm 0.08 \mathrm{~b}$ & $2.88 \pm 0.08 \mathrm{~cd}$ & $0.31 \pm 0.02 \mathrm{bc}$ \\
T3 & $7.98 \pm 0.04 \mathrm{~b}$ & $2.99 \pm 0.02 \mathrm{bc}$ & $0.34 \pm 0.04 \mathrm{bc}$ \\
T4 & $8.10 \pm 0.19 \mathrm{~b}$ & $3.04 \pm 0.06 \mathrm{~b}$ & $0.36 \pm 0.02 \mathrm{~b}$ \\
T5 & $7.83 \pm 0.42 \mathrm{c}$ & $2.93 \pm 0.07 \mathrm{bcd}$ & $0.30 \pm 0.01 \mathrm{c}$ \\
\hline
\end{tabular}

Means within a column followed by the same letter(s) are not significantly different $(P<0.05)$. Control (T0), $100 \mathrm{mM} \mathrm{NaCl}+0$ $\mu \mathrm{M} \mathrm{Se}$ (T1), $100 \mathrm{mM} \mathrm{NaCl}+2 \mu \mathrm{M} \mathrm{Se}$ (T2), $100 \mathrm{mM} \mathrm{NaCl}+4 \mu \mathrm{M} \mathrm{Se}$ (T3), $100 \mathrm{mM} \mathrm{NaCl}+8 \mu \mathrm{M} \mathrm{Se}$ (T4), $100 \mathrm{mM} \mathrm{NaCl}+16 \mu \mathrm{M} \mathrm{Se}$ (T5).

\section{Lipid peroxidation}

The membrane lipid peroxidation measured as MDA content (Fig. 1). Compared to the control, salt stress caused a significant increase in the content of MDA in melon seedlings. Whereas, Se reversed the adverse effect of $\mathrm{NaCl}$ and caused a significant decrease in MDA at Se concentrations, as compared with salt-stressed without Se addition. These results indicated that Se supplementation treatment significantly protected melon seedlings from damage by salt stress.

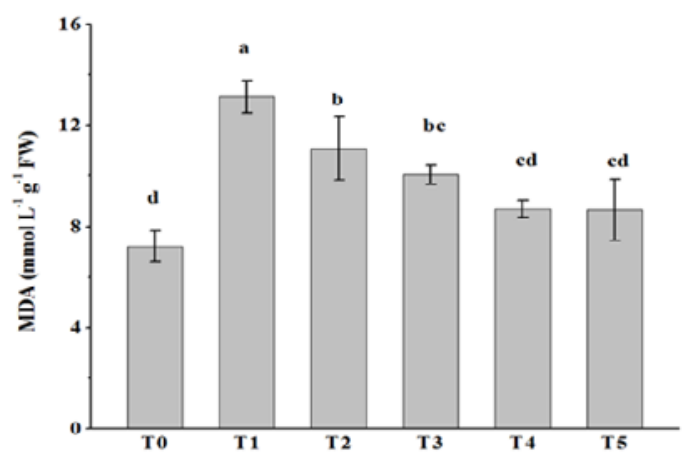

Fig. 1 Effects of Se supplementation on the content of MDA of melon seedlings under salt stress. Means within a column followed by the same letter(s) are not significantly different $(P<0.05)$. Control (T0), $100 \mathrm{mM} \mathrm{NaCl}+0 \mu \mathrm{M}$ Se (T1), $100 \mathrm{mM} \mathrm{NaCl}+2 \mu \mathrm{M} \mathrm{Se}$ (T2), 100 $\mathrm{mM} \mathrm{NaCl}+4 \mu \mathrm{M} \mathrm{Se}$ (T3), $100 \mathrm{mM} \mathrm{NaCl}+8 \mu \mathrm{M} \mathrm{Se}$ (T4), $100 \mathrm{mM}$ $\mathrm{NaCl}+16 \mu \mathrm{M} \mathrm{Se}$ (T5).

\section{Electrolyte leakage}

Data showed that the plants supplemented with $\mathrm{NaCl}$ exhibited a significant increase in electrolyte leakage compared 
to control (Fig. 2). Whereas, 4-16 $\mu \mathrm{M}$ Se treatments alleviated the adverse effect of $\mathrm{NaCl}$ and caused a significant decrease in electrolyte leakage in seedlings, relative to $\mathrm{NaCl}$-stressed plants grown without Se addition. However, application of $2 \mu \mathrm{M}$ Se on plants grown with $\mathrm{NaCl}$ did not decrease for this parameter.

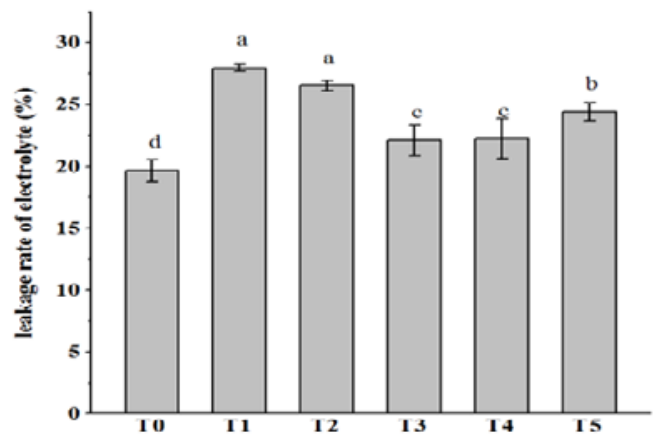

Fig. 2 Effects of Se supplementation on electrolyte leakage of melon seedlings under salt stress. Means within a column followed by the same letter(s) are not significantly different $(P<0.05)$. Control (T0), $100 \mathrm{mM} \mathrm{NaCl}+0 \mu \mathrm{M} \mathrm{Se}$ (T1), $100 \mathrm{mM} \mathrm{NaCl}+2 \mu \mathrm{M} \mathrm{Se}$ (T2), 100 $\mathrm{mM} \mathrm{NaCl}+4 \mu \mathrm{M} \mathrm{Se}$ (T3), $100 \mathrm{mM} \mathrm{NaCl}+8 \mu \mathrm{M} \mathrm{Se}$ (T4), $100 \mathrm{mM}$ $\mathrm{NaCl}+16 \mu \mathrm{M} \mathrm{Se}$ (T5).

\section{Activity of antioxidant enzymes}

The effects of different concentrations Se treatments on SOD, POD and CAT activities in melon seedlings exposed to salt stress were shown in Fig. 3. Salt stress alone caused a significant increased in the activities of SOD, POD and CAT compared with the control.

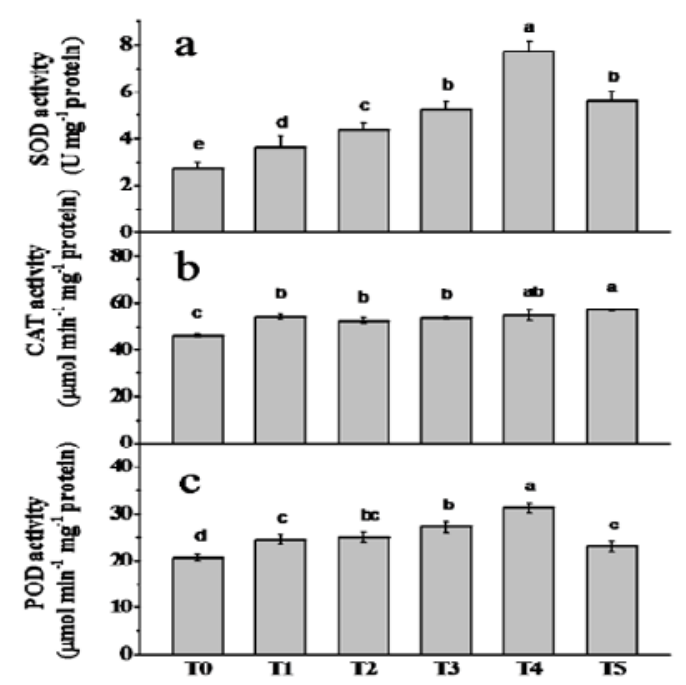

Fig. 3 Effects of Se supplementation on antioxidant enzyme activity of melon seedlings under salt stress. Means within a column followed by the same letter(s) are not significantly different $(P<0.05)$. Control (T0), $100 \mathrm{mM} \mathrm{NaCl}+0 \mu \mathrm{M} \mathrm{Se}$ (T1), $100 \mathrm{mM} \mathrm{NaCl}+2 \mu \mathrm{M} \mathrm{Se}$ (T2), $100 \mathrm{mM} \mathrm{NaCl}+4 \mu \mathrm{M} \mathrm{Se}$ (T3), $100 \mathrm{mM} \mathrm{NaCl}+8 \mu \mathrm{M} \mathrm{Se}$ (T4), 100 $\mathrm{mM} \mathrm{NaCl}+16 \mu \mathrm{M} \mathrm{Se}$ (T5).

The activities of SOD and POD in seedlings exhibited similar changes in response to Se concentrations. SOD activity increased progressively with Se concentrations $(2-8 \mu \mathrm{M})$ was being the highest value at $8 \mu \mathrm{M}$ Se. However, POD activity significantly increased at 4-8 $\mu \mathrm{M}$ Se treatments compared to salt-stressed plant without Se supply. In plants treated with 2-8 $\mu \mathrm{M}$ Se, CAT activity remained unchanged in comparison with $\mathrm{NaCl}$-stressed plants grown without Se addition. Nevertheless, CAT activity increased at $16 \mu \mathrm{M}$ Se supplementation combined with $\mathrm{NaCl}$ treatment.

\section{Discussion}

Restrained plant growth is an obvious result of salt stress; many authors report that plant growth and development were inhibited by salt stress $[16,17]$. In the present study, we also found treatment with salt stress retarded of melon seedlings growth. However, it was observed that Se supplementation decreased the deleterious effect of salt stress on the growth of melon (Tab. 1). Simultaneously, the optimum of salt-stressed seedlings growth observed at concentration $8 \mu \mathrm{M}$ of Se treatment, whereas at high concentrations $(16 \mu \mathrm{M})$ the beneficial effect declined, the results are in agreement with Kong et al [9]. It might due to higher concentrations of Se decrease protein synthesis and premature death of the plant [6]. HawrylakNowak [8] also reported that 5-10 $\mu \mathrm{M}$ Se resulted in notable increase in roots and shoots biomass.

A wide range of environment stresses enhances production of ROS and induces extensive lipid peroxidation [18]. The level of MDA, a product of lipid peroxidation, has often been used an indicator of oxidative damage in membranes [16]. Under our experimental conditions, salt stress increased significantly the MDA content compared to control. An increase in MDA level in response to increasing salinity was also found by Ellouzi et al. [19]. However, there was a decrease of MDA content in all the Se treatments salt-stressed melon seedlings relative to $\mathrm{NaCl}$-stressed plants grown without Se addition. MDA content decreased, this could be indicative of Se enhancement salt tolerance and the decline of lipid peroxidation, as proved by Hawrylak-Nowak et al. [8], who reported that application of Se decreased MDA content in cucumber.

Electrolyte leakage has been thought to be another method of oxidative stress assessment [4]. Treatment of seedlings with salt stress resulted in a marked increase in electrolyte leakage. However, electrolyte leakage of salt-stressed seedlings decreased compared to salt-stressed without Se supply when exposed to concentrations ranging 4-16 $\mu \mathrm{M}$ Se. Se supplication decreased significantly the electrolyte leakage at salt stress indicating the important role concerning membrane integrity in melon seedlings. A decrease in electrolyte leakage in response to increasing Se treatments was also found by Kong et al. [9] in salt-tolerant sorrel seedlings; they reported the reduced electrolyte leakage may be a direct consequence of Se treatment.

SOD is a key enzyme that plays an important role of oxidative stress [3]. In our experiments, the activity of SOD was increased under salt stress, at the same time, a gradual increase was observed in lower concentrations $(2-8 \mu \mathrm{M})$ Se supply with salt-stress seedlings (Fig. 3a). The reason of that Se might alter SOD gene expression [20]. However, SOD enzymes activities became weak at $16 \mu \mathrm{M}$ Se treatment. The cause of Se might act as an antioxidant at low concentrations, but as a pro-oxidant at higher ones [21]. Moreover, plant under stress might produce some else defense mechanisms to protect themselves from harmful effect of oxidative stress [22], such as it could be related to non-enzymatic antioxidative processes promoted by antioxidant compounds [17]. 
POD protects the cells from the damaging effects of $\mathrm{H}_{2} \mathrm{O}_{2}$ accumulation [20]. In our study, POD activity of salt-stressed seedlings increased when exposed to concentrations $4-8 \mu \mathrm{M}$ Se. However, at concentration $16 \mu \mathrm{M}$ Se, there were adverse effects on POD activity compared with that at $8 \mu \mathrm{M} \mathrm{Se}$ (Fig. 3c). Our result demonstrated that the role of Se could enhance the POD activity. This is in agreement with the findings of Yao et al. [12], who found that Se supply significantly increased POD activity under drought stress.

Some authors indicate that the CAT/POD system might act cooperatively to remove $\mathrm{H}_{2} \mathrm{O}_{2}$ [23]. In our study, CAT activity was significantly increased upon exposure to salt stress. In addition, no increase was observed in lower Se concentration (2-8 $\mu \mathrm{M})$ compared to salt-stressed without Se supply (Fig. 3b). Many authors also reported that CAT activity did not change with Se addition $[9,20]$. Whereas $16 \mu \mathrm{M}$ Se supplementation salt-stressed seedlings significantly increased the activity of CAT. The reason for this could be that CAT seems to play a complementary role in seedlings in regulating the $\mathrm{H}_{2} \mathrm{O}_{2}$ cellular concentration [17].

Our results indicated that Se supplementation decrease of lipid peroxidation and electrolyte leakage under salt stress. Seinduced enhancement of anti-oxidative enzymes revealed that melon has a high capacity to activate protective mechanisms against the oxidative damage generated by salt stress. It is concluded that Se supplementation alleviated the damaging effect of salt stress through increasing antioxidant defense system. The growth and physiological responses of seedlings were different depending on the Se concentration.

\section{Acknowledgments}

This work was supported by the Natural Science Foundation of Anhui Province, China (1208085QC54), the Scientific Research Foundation for Young Scientists of Anhui Agriculture University, China (2011zb006), and the Scientific Research Foundation for Introducing Talents of Anhui Agriculture University, China (yi2011-38).

\section{Authors' contributions}

The following declarations about authors' contributions to the research have been made: conceived and designed the study: HK, ZL; performed the experiments: WJ, YY; wrote the paper: HK; reviewed and edited the manuscript: ZL.

\section{References}

1. Tarchoune I, Sgherri C, Izzo R, Lachaâl M, Navari-Izzo F, Ouerghi Z. Changes in the antioxidative systems of Ocimum basilicum L. (cv. Fine) under different sodium salts. Acta Physiol Plant. 2012;34(5):1873-1881. http://dx.doi.org/10.1007/s11738-012-0985-z

2. Maia JM, Costa de Macedo CE, Voigt EL, Freitas JBS, Silveira JAG. Antioxidative enzymatic protection in leaves of two contrasting cowpea cultivars under salinity. Biol Plant. 2010;54(1):159-163. http://dx.doi. org/10.1007/s10535-010-0026-y

3. Foyer CH, Lelandais M, Kunert KJ. Photooxidative stress in plants. Physiol Plant. 1994;92(4):696-717. http://dx.doi.org/10.1111/j.1399-3054.1994. tb03042.x

4. Ben Amor N, Megdiche W, Jiménez A, Sevilla F, Abdelly C. The effect of calcium on the antioxidant systems in the halophyte Cakile maritima under salt stress. Acta Physiol Plant. 2009;32(3):453-461. http://dx.doi. org/10.1007/s11738-009-0420-2

5. Hernandez JA, Ferrer MA, Jimenez A, Barcelo AR, Sevilla F. Antioxidant systems and $\mathrm{O}_{2-} / \mathrm{H}_{2} \mathrm{O}_{2}$ production in the apoplast of Pea leaves. Its relation with salt-induced necrotic lesions in minor veins. Plant Physiol. 2001;127(3):817-831. http://dx.doi.org/10.1104/pp.010188

6. Terry N, Zayed AM, de Souza MP, Tarun AS. Selenium in higher plants. Annu Rev Plant Physiol Plant Mol Biol. 2000;51(1):401-432. http://dx.doi. org/10.1146/annurev.arplant.51.1.401

7. Ríos JJ, Blasco B, Cervilla LM, Rosales MA, Sanchez-Rodriguez E, Romero $\mathrm{L}$, et al. Production and detoxification of $\mathrm{H}_{2} \mathrm{O}_{2}$ in lettuce plants exposed to selenium: selenium and antioxidant system in lettuce plants. Ann Appl Biol. 2009;154(1):107-116. http://dx.doi.org/10.1111/j.1744-7348.2008.00276.x

8. Hawrylak-Nowak B. Beneficial effects of exogenous selenium in cucumber seedlings subjected to salt stress. Biol Trace Elem Res. 2009;132(1-3):259269. http://dx.doi.org/10.1007/s12011-009-8402-1

9. Kong L, Wang M, Bi D. Selenium modulates the activities of antioxidant enzymes, osmotic homeostasis and promotes the growth of sorrel seedlings under salt stress. Plant Growth Regul. 2005;45(2):155-163. http://dx.doi. org/10.1007/s10725-005-1893-7

10. Hawrylak-Nowak B, Matraszek R, Szymańska M. Selenium modifies the effect of short-term chilling stress on cucumber plants. Biol Trace Elem Res. 2010;138(1-3):307-315. http://dx.doi.org/10.1007/s12011-010-8613-5

11. Mroczek-Zdyrska M, Wójcik M. The influence of selenium on root growth and oxidative stress induced by lead in Vicia faba L. minor plants. Biol Trace Elem Res. 2011;147(1-3):320-328. http://dx.doi.org/10.1007/ s12011-011-9292-6

12. Yao X, Chu J, Wang G. Effects of selenium on wheat seedlings under drought stress. Biol Trace Elem Res. 2009;130(3):283-290. http://dx.doi. org/10.1007/s12011-009-8328-7

13. Syeed S, Anjum NA, Nazar R, Iqbal N, Masood A, Khan NA. Salicylic acid-mediated changes in photosynthesis, nutrients content and antioxidant metabolism in two mustard (Brassica juncea L.) cultivars differing in salt tolerance. Acta Physiol Plant. 2010;33(3):877-886. http://dx.doi. org/10.1007/s11738-010-0614-7

14. Stewart RRC, Bewley JD. Lipid peroxidation associated with accelerated aging of soybean axes. Plant Physiol. 1980;65(2):245-248. http://dx.doi. org/10.1104/pp.65.2.245

15. Cakmak I, Marschner H. Magnesium deficiency and high light intensity enhance activities of superoxide dismutase, ascorbate peroxidase, and glutathione reductase in bean leaves. Plant Physiol. 1992;98(4):1222-1227. http://dx.doi.org/10.1104/pp.98.4.1222

16. Li JT, Qiu ZB, Zhang XW, Wang LS. Exogenous hydrogen peroxide can enhance tolerance of wheat seedlings to salt stress. Acta Physiol Plant. 2010;33(3):835-842. http://dx.doi.org/10.1007/s11738-010-0608-5

17. Sergio L, De Paola A, Cantore V, Pieralice M, Cascarano NA, Bianco VV, et al. Effect of salt stress on growth parameters, enzymatic antioxidant system, and lipid peroxidation in wild chicory (Cichorium intybus L.). Acta Physiol Plant. 2012;34(6):2349-2358. http://dx.doi.org/10.1007/ s11738-012-1038-3

18. Yoshimura K, Miyao K, Gaber A, Takeda T, Kanaboshi H, Miyasaka H, et al. Enhancement of stress tolerance in transgenic tobacco plants overexpressing Chlamydomonas glutathione peroxidase in chloroplasts or cytosol. Plant J. 2004;37(1):21-33. http://dx.doi.org/10.1046/j.1365-313X.2003.01930.x

19. Ellouzi H, Ben Hamed K, Cela J, Munné-Bosch S, Abdelly C. Early effects of salt stress on the physiological and oxidative status of Cakile maritima (halophyte) and Arabidopsis thaliana (glycophyte). Physiol Plant. 2011;142(2):128-143. http://dx.doi.org/10.1111/j.1399-3054.2011.01450.x

20. Djanaguiraman M, Devi DD, Shanker AK, Sheeba JA, Bangarusamy U. Selenium - an antioxidative protectant in soybean during senescence. Plant Soil. 2005;272(1-2):77-86. http://dx.doi.org/10.1007/s11104-004-4039-1 21. Hartikainen H, Xue T, Piironen V. Selenium as an anti-oxidant and 
pro-oxidant in ryegrass. Plant Soil. 2000;225(1-2):193-200. http://dx.doi. org/10.1023/A:1026512921026

22. Idrees $M$, Naeem $M, A f t a b T$, Khan MMA. Salicylic acid mitigates salinity stress by improving antioxidant defence system and enhances vincristine and vinblastine alkaloids production in periwinkle [Catharanthus roseus
(L.) G. Don]. Acta Physiol Plant. 2010;33(3):987-999. http://dx.doi. org/10.1007/s11738-010-0631-6

23. Willekens $\mathrm{H}$. Catalase is a sink for $\mathrm{H}_{2} \mathrm{O}_{2}$ and is indispensable for stress defence in C3 plants. EMBO J. 1997;16(16):4806-4816. http://dx.doi. org/10.1093/emboj/16.16.4806 